DOI: 10.2478/pof-2018-0025

VOLUME 10, ISSUE 2, 2018

ISSN: $2036-5438$

\title{
The Secession Issue and Territorial Autonomy in Spain: Bicameralism Revisited
}

by

Alberto López-Basaguren*

Perspectives on Federalism, Vol. 10, issue 2, 2018 


\section{Abstract}

The Spanish Constitution defines the Senate as 'Chamber of territorial representation'. But in the Senate the provinces are represented, not the Autonomous Communities. The Senate is a Chamber of 'sober second thought', subordinated to the lower House, whose will prevails in the event of discrepancy. It lacks specific powers with regard to territorial autonomy; in spite of this, there has been an attempt to assign it relevance in this sphere by creating a General Committee on Autonomous Communities. By way of exception the Senate is exclusively responsible for the decision to authorize the Government to apply measures of 'federal coercion'. This constitutional provision was first activated in October 2017, in the context of the secessionist process in Catalonia, as a result of the repeated noncompliance by the authorities of the resolutions of the Constitutional Court (CC), which concluded with the Unilateral Declaration of Independence (UDI) by Parliament at the same time as the adoption of the measures of federal coercion. The Senate demonstrated that even in a case in which it has the reserved competence, as in the authorization of the adoption of measures of federal coercion, it lacks the capacity to be a federal Chamber.

Key-words

bicameralism, Senate, Spain, Catalonia, secession, federal coercion 


\section{The Spanish Senate as a second Chamber: general remarks}

The Spanish Constitution -sec. 69(1) - states, quite categorically, that the Senate is the House of territorial representation'. This is, however, an affirmation that requires clarification in order to understand the nature of the Senate in Spain; in other words, what those who form it -the Senators- represent and what functions are assumed by the House as an element of legislative power.

The first clarification that needs to be made is that the Senators only very marginally represent the seventeen Autonomous Communities (ACs); in other words, the territories the 'nationalities and regions'- that are holders of political autonomy according to sec. 2 of the Constitution. The Senators are directly elected by the voters; the constituency is the Province - the territorial organisation of Spain, consolidated early in the $19^{\text {th }}$ century, which replaced the old territorial division of the ancien régime-; in each Province four Senators are elected via a plurinominal first-past-the-post electoral system with open lists ${ }^{\mathrm{II}}$, in which each voter may cast a vote for a maximum of three candidates, in order regularly to permit the minority to obtain a seat. In this way, 208 Senators are elected in the Provinces. Meanwhile, the Constitution establishes that, in addition, each AC shall designate one Senator and one more per million inhabitants. An appointment that shall correspond to the Regional Parliament, in the terms established by the respective Statute of Autonomy (SA) 'which shall, in any case, guarantee adequate proportional representation' sec. 69(5) Const.-. In the current legislature a total of 58 Senators have been appointed by the AC, less than a quarter of the whole House.

In view of the composition of the Senate, there is an obvious conclusion: the Senate is a Chamber of territorial representation; not of the new AC created according to the Constitution, but of the old administrative- territorial - structure of the State. Given the characteristics of the ACs, this results in a significant imbalance in how they are represented in the Senate, benefitting those comprising a greater number of provinces the largest in territorial terms- ${ }^{\text {III }}$, which are, in very significant cases, those with smaller, ageing populations. This has very significant effects upon the political majority in the upper House, favouring both the representation of the two main traditional parties and a conservative majority ${ }^{\mathrm{IV}}$. 
The composition of the Senate on a provincial basis rather than on that of the ACs has a historical justification, since when the Constitution was adopted (1978), the new territorial structure had not yet been determined; neither which territories would become AC nor whether all the territories would do so. The territorial structure was an issue that had remained unresolved when the short life of the Second Republic (1931-1939) came to an abrupt end: initially, only Catalonia and, subsequently, the Basque Country, appeared to be destined to become autonomous regions, but it was not long before other territories began to demand autonomy. Therefore, the structure of the State, divided in its entirety into ACs, is a result subsequent to the adoption of the Constitution, in which, generally speaking, the provisions related to territorial autonomy are limited to regulation of the process to create the ACs.

The traditional territorial structure, the only one in existence when the Constitution was adopted, was that of the Provinces. The original constitutional regulation was, therefore, understandable; unlike the fact that there has been no modification of the composition of the Senate, to turn it into a Chamber of representation of the autonomous territories, when all the territories have been ACs for thirty-five years now.

The Spanish Senate is a House of sober second thought. With regard to the procedure of drafting laws, the Senate has general functions; so it participates, along with the lower Chamber, in the drafting of all the laws of the State. But it is a Chamber subordinated to the Congreso de los Diputados. Even when legislative initiative is exercised by the Senate Private Bills- debate and adoption have to take place previously in the lower House. The Senate only debates and votes on texts that have already been debated and voted upon in the Congreso de los Diputados. The Senate can veto the text submitted by Congress; but this requires an overall majority of the Chamber and the veto may be overturned by the lower House, either immediately by absolute majority or, two months after the Senate veto, by simple majority. Alternatively, the Senate may introduce amendments to the text submitted by the lower Chamber; but when this occurs the text is returned to Congress for final approval, deciding -by simple majority- whether or not to accept the modifications introduced by the Senate. The subordination of the Senate is also clear in the specific case of Organic Acts, which require approval by an overall majority in Congress in a final vote on the bill as a whole' -sec. 81 Const.- ${ }^{\mathrm{V}}$. Finally, the Senate is completely alienated from the process to validate Decree-Laws, the temporary Statutory Instruments invested with the 
force of an Act, although they are passed by the Government. To remain in force, the Decree-Laws have to be validated by the lower House within 30 days of their promulgation, with the Senate having no role in this process (sec. 86 Const.). The DecreeLaws have become a quite common way to legislate, this alienation being of great significance in the law-making process.

The Senate, on occasions, has powers on equal terms with the Congress. This is the case of the procedure to reform the Constitution, although in the case of disagreement, the lower House can impose its opinion by a qualified majority -sec. 166 and ff. Const.-, the procedure for ratification of international Treaties, when parliamentary authorisation is required -sec. 94 Const.-, control of government activity -sec. 109-111 Const.-, or the appointment of judges to the Constitutional Court -sec. 159 Const. - or to other State organs. But these are exceptions rather than the rule.

Finally, there are decisive issues in the parliamentary system in which the decision corresponds exclusively to Congress, without any Senate intervention whatsoever. This is the case of both the election of the President of the Government (Prime Minister) -sec. 99 Const. - and the demand for Government accountability (vote of confidence -sec. 112- and vote of censure -sec. 113-).

In conclusion, Spain has an imbalanced bicameral parliament, with absolute dominance of the lower Chamber which, with very few exceptions, has the capacity to impose its will in the event of discrepancy between the two Houses, almost immediately, especially in the procedure of drafting laws. Moreover, the second Chamber is completely excluded from what W. Bagehot (1873: 78) regarded as the 'principal business' of a legislature in a parliamentary system: 'making and keeping an executive', although 'it is chosen, in name, to make laws'.

\section{Senate and territorial autonomy: general overview}

With regard to the Senate's powers in relation to its definition as 'House of territorial representation' it is significant that, apart from the exception that will be analyzed later and which, indeed, is the main focus of this work-, the Senate is set to play no significant role, with no power that justifies that condition. 
First of all, what is most surprising is the Senate's exclusion from effective participation in the determination of the content of the SA, the internal or territorial Constitution of each AC, its 'basic institutional rule', as defined in sec. 147(1) Const. Its participation is merely formal, in the process of final adoption of the SA as Organic Act, but when its contents have already been decided upon. In the Spanish system the SA is not, in the fullest sense, an exercise of the constitutional autonomy of the territory, but is rather a State's Act -as far as it is an Organic Act-, adopted via a complex process, initiated by the parliamentary representatives of the territory, who present their project to the Select Committee on Constitution in the Congreso de los Diputados, where the definitive text is agreed upon between a delegation of the representatives of the territory and the members of the Select Committee. The resulting text is submitted to referendum before the electorate of the territory and, if endorsed, is processed in Parliament (Cortes Generales) for its adoption as Organic Act (Aguado 1996). The Senate only participates in this final phase, in which the Chambers do no more than formally validate the text, now -at least, politically- unmodifiable.

The Constitution, by contrast, establishes three questions in which the Senate decides in conjunction with Congress, on an equal footing, without being subordinated, as is generally the case. On the one hand, it corresponds to the Cortes Generales, 'by overall majority of the members of each House' to assess the need 'to harmonize the rulemaking provisions of the Self-Governing Communities' to enact what have been called 'harmonization Acts' -sec. 150(3) Const.-. This is, in any case, a type of Act which, following the frustrated attempt by the LOAPA - Organic Act of harmonization on the process of territorial autonomy-, declared substantially unconstitutional by the Constitutional Court regarding the quest to be an 'Act of harmonization' (CC Ruling CCR- 76/1983, of August 5) (Muñoz Machado 1983; Cruz Villalón 1983), has been practically disabled, without further mention of the possibility of its use.

On the other hand, sec. 158(2) Const. establishes that the Cortes Generales -i.e., both Houses - shall distribute between the ACs and the provinces -'where appropriate'- the financial resources from the fund that will have to be created 'with the aim of redressing inter-territorial economic imbalances and implementing the principle of solidarity'. But this Fund, which seemed to be contemplated in the Constitution as an equalization fund, plays a completely marginal role in the system of distribution of financial resources, while the 
equalization is channelled via other funds (López-Laborda 2012; Zabalza et al. 2011; Vilalta 2016).

Finally, cooperation between the ACs, regarding issues different from the management and rendering of services in matters pertaining to the latter, shall require authorization by the Cortes Generales -sec. 145(2) Const.-. These are, therefore, what might be considered extraordinary cooperation agreements between ACs, virtually non-existent, in the context of extremely weak horizontal relations of inter-governmental cooperation (García Morales 2013: 132 ff.; 2016: 96 ff.).

In the three cases in which the Constitution attributes to the Senate an intervention in parity with Congress vis-à-vis territorial autonomy, these are questions that, at least in practice, have become almost irrelevant. Generally speaking, therefore, one must conclude that the Senate plays no special role with regard to territorial autonomy: it lacks significant specific powers relating to territorial autonomy; it is excluded from the establishment of the contents of the territory's internal Constitution - SA-; and, on the rare occasion when it is assigned participation which is not subordinated to lower House, it is with regard to issues that have been proven irrelevant.

\section{The General Committee on the Autonomous Communities}

The parliamentary political forces have attempted to increase the importance of the Senate vis-à-vis territorial autonomy. The most significant initiative in this respect was taken in 1994, with the reform of the Senate Standing Orders ${ }^{\mathrm{VI}}$. This included, most importantly, one question of particular interest in relation to the subject of this work. It incorporated the most significant novelty during these years: the creation in the Senate of a General Committee on AC -sec. 55- (Visiedo 1997; García-Escudero 1994; Ripollés 1995; Morales et al. 1994).

With the creation of this General Committee the aim was, on the one hand, to establish within the Senate a Committee that was particularly relevant from the formal point of view, in an attempt to differentiate it from the other Select Committees of the House. Furthermore, the idea was for this Committee to be the catalyst for all reflection and debate on territorial autonomy within Spanish legislature as a whole, for it to be the forum for decisive debates on territorial autonomy, the benchmark for reflections on the latter and the driving force 
behind initiatives in this area. And it was a case, finally, in order that all this might be possible, of it not being an exclusively internal Committee within the Chamber, but the scenario in which the representatives of the governments of the ACs, and in particular their respective presidents, could participate in these reflections and in the promotion of the State Parliament's initiatives with regard to territorial autonomy. To facilitate all the above, Senate Standing Orders introduced a significant symbolic novelty: the possibility that interventions taking place in the sessions of the General Committee may be performed in any of the official languages that, along with Castilian, have official status in an AC; interventions that shall be reproduced in the Official Report (Hansard) in the language in which they were delivered and in Castilian' -sec. 56. bis (9) of the Standing Orders ${ }^{\mathrm{VII}}$ -

The objectives indicated are quite clearly expressed in sec. 56 of the new text of the Senate Standing Orders adopted in 1994. The aim is for this to be a Committee of a general nature regarding territorial autonomy. So, all the Senators appointed by the ACs and who are not members of the General Committee should be 'advised in advance of its sessions' which they may attend and participate in all debates -sec. 56 bis (1) of the Standing OrdersVIII. Also entitled to participate in the debates and sessions, apart from members of the Central Government, are the members of the Governments of the ACs, their First Ministers primarily -sec. 56 bis (2) of the Standing Orders-. Acknowledgement of the important role of the Governments of the ACs is also evident in the fact that any Government of the latter may request that the General Committee be convened -sec. 56 bis (3)-.

The functions of debate, promotion and legislative procedure of the General Committee are of a general, all-embracing nature, with regard to all that concerns territorial autonomy, in the attempt to make the Committee the lead player in this area, as is evidenced by the extensive and detailed sec. 56 of the Standing Orders in which its powers are specified.

Finally, it should be noted, in the same sense, that the new drafting of the Senate Standing Orders establishes that the General Committee shall hold once a year, on a mandatory basis prior to the end of the first period of sessions -in other words, before the end of each year- a general debate on the system of territorial autonomy (a session whose sole item on the agenda shall be that of 'evaluating the situation of the State of Autonomies' -sec. 56 bis (7)-), after which members may pass the Motions they deem to be appropriate. An annual debate in the General Committee which is added to the general debate 
on territorial autonomy, exclusively dedicated to this question, which, similarly, must be held every year in the Plenary Session of the House -sec. 56 bis (8) of the Standing Orders-.

The creation of the General Committee on the Autonomous Communities raised hopes in some sectors regarding the prominence that its activity would attribute to the Senate in relation to territorial autonomy. The experience, however, has been largely frustrating. Although during the initial years, following the creation of that General Committee, such a debate attracted some attention, the similar debate in the Plenary Session has attracted more attention than the former. But even the latter has languished considerably. To the traditional absence of members of the Government of the AC of the Basque Country and in particular, of its president-, has been added, in recent years, that of the Government of Catalonia, which, without a doubt, has reduced the significance of the debate. But above all it has been the absence of significant impact of the questions raised in the debates and, in general, within the General Committee, which has largely dashed the hopes inspired in some by this initiative (Varela 2006: 149-150) ${ }^{\mathrm{IX}}$. On the other hand, the nationalist parties Basque and Catalan in particular, but also, in certain parliamentary circumstances, those of the Canary Islands or others- have continued to make very effective use of their votes in the lower Chamber, when the Government majority has required them, meaning that, for these parties, the real House of territorial representation has always been the Congreso de los Diputados.

One can conclude, therefore, that the Senate is not a House of territorial representation, from neither a structural nor a functional point of view (Punset 2006: 112).

\section{Federal Coercion and the Senate's Role}

In this context of subordination of the Senate to the lower House and of absence of any significant special power vis-à-vis territorial autonomy, one exception stands out, in which the Senate alone decides, without any intervention by the lower House: authorizing the Government to apply measures of 'federal coercion'.

The Spanish Constitution -sec. 155 - regulates this concept in a manner taken directly from sec. 37 of the German Grundgesetz $(G G)^{\mathrm{x}}$. In this respect, it establishes, firstly, the element of fact or the necessary condition for the adoption of measures of federal coercion: 'If a Self-governing Community [AC] does not fulfill the obligations imposed 
upon it by the Constitution or other laws, or acts in a way that is seriously prejudicial to the general interest of Spain' -sec. 155(1)-. Unlike the regulation established in the Grundgesetr, which only refers to non-fulfillment of legal obligations, the Spanish Constitution adds a second element - serious impact upon the general interest-. There has been debate as to whether this second element adds something different from the first or whether it simply repeats this. The intention to autonomize the definition of the 'general interest' and who should define it is an old debate (Requejo 2013). In my opinion, considering the serious impact upon the general interest as a reason to apply federal coercion different from the non-fulfilment of legal obligations is extremely problematic, not to say difficult to sustain. On the one hand, if we bear in mind that control of the actions of the ACs corresponds to the law courts - with the particularities that affect this control on the part of the CC, especially with regard to suspension of the territories' actions when challenged by the Government - (López-Basaguren 2017a: 303 ff.), the non-fulfilment of legal obligations that justifies recourse to federal coercion must refer to non-compliance with final court decisions. Any discrepancy between the interpretation of the constitutional and legal obligations of an AC cannot be imposed by the Government, but must be ruled upon in court $^{\mathrm{XI}}$. If the issue is addressed in these terms, is it possible to conceive of serious prejudice to the general interest on the part of an AC through actions that do not consist in non-compliance with the decisions of the law courts? However, with regard to the recent application of the measures of federal coercion in Catalonia there seems to be a widely held view that the serious impact upon the general interest is a reason in itself to justify federal coercion different from the non-fulfilment of legal obligations. Although we do not know what these acts or situations would be.

Regarding the process of application of measures of federal coercion, the Spanish Constitution requires certain prior steps that do not exist in the Grundgesetr. While in the latter non-fulfilment of constitutional and legal obligations directly justifies taking 'the necessary steps to compel the Land to comply with its duties', the Spanish Constitution requires, previously, the lodging of 'a complaint before the President of the Self-governing Community [AC]' -which, in the opinion of E. García de Enterría (1983: 167), evoked what is provided for in sec. 84(5) GG-. Only in the event of failure 'to receive satisfaction', may the Central Government 'take all measures necessary to compel the Community to meet said obligations' or -in accordance with the addition made to the original German 
constitutional text- 'to protect the above mentioned general interest'. Finally, the Spanish Constitution - in a very similar drafting to that contained in sec. 37(2) GG- establishes that, in order to apply the said measures of federal coercion 'the Government may issue instructions to all the authorities of the Self-governing Communities [AC]'.

The application of measures of federal coercion by the Government requires, in both the German Grundgesetz, and the Spanish Constitution, prior authorisation by the second Chamber; in the Spanish case, by overall majority. Herein lies the radical difference between the German Bundesrat and the Spanish Senate regarding the question of territorial representation. In the German case, the required authorisation by the Bundesrat has a clear sense of territorial 'consensus' in the adoption of the measures of coercion, given the exceptional nature of the Bundesrat in the world of second federal chambers, particularly in relation to its composition (Kotzur 2006).

In light of what has been said on preceding pages, the requirement of authorisation by the Senate does not represent, in Spain, the idea of the ACs reaching a consensus in the adoption of the aforementioned measures of coercion. This is clear and practical evidence of the contradiction between the constitutional definition of the Senate as "Chamber of territorial representation' and its true nature, as a Chamber that, on the basis of representation of the provinces, distorts representation, producing majorities far-removed from reality and, generally, of a conservative leaning and, in any case, strongly favouring the existing political majority at any given moment. In other words, in the Spanish case, the introduction of the requirement of authorisation by the second Chamber does not represent, as it does in Germany, what might be termed a 'federal guarantee'.

As the CC has indicated, there is no doubt that the purpose of sec. 155 Const. is to guarantee the unity of the legal system (CCR 25/1981, of 2 July). In the virtually unanimous opinion of scholars, this is an absolutely extraordinary measure, in view of the particular requirements, the precautions established in the Constitution and the enormous political significance of recourse to federal coercion. An extraordinary nature that was apparent in the debate on the drafting of the Constitution and that has been confirmed in the practical functioning of the political system (Vírgala Foruria 2005: 58-9). This has also been reiterated by the $\mathrm{CC}^{\mathrm{XII}}$. And so it has become consolidated in the political consciousness. The fact that this constitutional provision has never been applied in the country (Germany) that served as the model for the regulation of federal coercion in the 
Constitution reaffirmed this notion of exceptionality. All this led to the idea that this was a provision intended, fundamentally, not to be applied; or, rather, the use of which was not to be forced. Which was not to deny its usefulness, insofar as its main function was considered to be not so much its practical application as the preventive effect arising from its presence in the Constitution (Ballart 1987: 92).

That awareness of the exceptional nature of federal coercion, the unknown quality of its application in the prototype-country and the political connotations of its application led to unwillingness to resort to this constitutional provision. Not even on the occasion of repeated disobedience of the CC's decisions by the Catalan authorities with regard to the staging of the referendum (the so-called 'consultation') of 9-N (2014), was there any intention to apply the measures of federal coercion to impose compliance with those legal obligations that were being violated. Although there had been warnings that the development of events would make it very difficult to avoid the application of measures of this kind (López-Basaguren, 2017a: 311), until very shortly before the events surrounding the referendum on self-determination of 1-O and the UDI (2017) the application of measures of federal coercion was regarded as unlikely.

There is significant evidence that the Government sought to avoid their application until the last moment. Although it did so, in my opinion, simply in an attempt to elude its responsibility in the hope that other institutions would assume responsibility for the actions that would render unnecessary the application of federal coercion. If, on the one hand, it appears that the government's majority attempted to 'normalize' in political -and legaldiscourse the measures included in sec. 155 of the Constitution, introducing it into 'ordinary' legislation ${ }^{\mathrm{XIII}}$, on the other hand, it strove to 'normalize' the 'coercive' measures beyond the procedure established in the Constitution, by way of measures with similar effects, but avoiding that procedure. Which would enable the Government to elude the political responsibility implicit in its implementation. This is what, in my view, was the objective of the reform of the Act regulating the CC - Organic Act 15/2015, of October 16-, assigning the CC the capacity, amongst other measures, to suspend from their duties authorities and civil servants who refused to comply with or implement its resolutions, or to impose periodic penalty fines - from 3,000 to 30,000 €- upon those authorities and civil servants, as well as those individuals who did not comply with them. This was, without a doubt, an attempt to render it unnecessary to recur to federal coercion, though it has 
proved to be an almost complete failure, to date at least ${ }^{\mathrm{XIV}}$, as the $\mathrm{CC}$ has not made use of its 'new' powers, in particular the possibility of suspending authorities and civil servants. The final recourse -too late, in the opinion of many- to 'federal coercion' can only be correctly understood, in my view, if these elements are taken into account.

\section{The Secession Issue in Catalonia: general overview}

In order to analyze the practical application of federal coercion and, in this area, the Senate's role, it is necessary to present a general picture of the political process of the claim for secession in Catalonia, insofar as recourse to this instrument has been the State's response to the most recent developments. The characteristics of this work, however, require a synthetic, schematic presentation, in order not to stray from its purpose $\mathrm{e}^{\mathrm{XV}}$.

The secessionist process in Catalonia began in 2012 $\mathrm{XVI}$, with a massive public demonstration on September 11 (national holiday in Catalonia, Diada), which would be repeated, in different ways, on the same holiday in successive years (Tornos Mas 2015). Furthermore, there have been two key moments in this process of popular mobilisation: the 'referendums' on independence of November 9, 2014 (9-N) and of October 1, 2017 (1O). This has been a short political process, of rapid development, in which the growth of support for secession has been meteoric, from traditionally very low levels until the process started in 2012. The initial approach focused on the demand for a 'referendum' (or 'consultation') on the political future of Catalonia, including independence ('right to decide'), achieving what was apparently overwhelming support in Catalan society (Tornos Mas 2014). A demand that was soon directly transformed into a demand for secession. The advocates of the secessionist claim have acted with haste and have successively proposed very close dates (18 months has been the time frame most repeated as an objective at different and successive moments). According to the arguments of the advocates of the secessionist demand - the most complete expression of which is to be found in the reports of the Council for national transition (Consell assessor per a la transició nacional) (de Miguel Bárcena 2016) ${ }^{\mathrm{XVII}}$-, the claim for secession would be supported by international Law, insofar as Catalonia, as a nation, has a right to the self-determination recognised in international Covenants on rights (1966). This interpretation would be endorsed by the International Court of Justice's (ICJ) Advisory Opinion on Kosovo, of July 22, 2010. Likewise, 
independence would not only be a democratically unquestionable objective, but would also, if it enjoyed majority social support, be democratically unassailable. Independence, moreover, would be quickly achieved, majority social support having been established, and would be even attainable in unilateral fashion. And it would be a peaceful and legal process, requiring only that the Catalan Parliament, as custodian of the sovereignty of the people of Catalonia, pass the laws that would 'disconnect' Catalonia from Spain.

This is not the place to enter into a debate on an approach such as that employed by the advocates of the secessionist demand. But I think it is clear to any observer minimally removed from the partisan defence of the process that the political and legal bases of this approach reveal highly questionable aspects. The interpretation of the right to selfdetermination does not correspond to its contents as defined by the international organisations with competence in this sphere; and neither does the understanding of the right to self-determination by the ICJ in its Advisory Opinion on Kosovo. The ICJ reiterates over and over again that this right is not what is under consideration - nor whether if in the case of Kosovo this is an instance of remedial secession. A negative answer that is extraordinarily significant, in view of the events preceding that UDI. One is struck by the fact that the authors of the secessionist discourse have not addressed - at least not openly - the two practical problems, the two inescapable challenges to the effectiveness of such a discourse: the capacity effectively to control the territory and sufficient recognition by the international community. It comes as a surprise, above all, because these are two questions that were explicitly indicated by the Supreme Court (SC) of Canada in the Reference on the secession of Quebec (1998) and by the ICJ in the case of Kosovo - much used in the defence of the legitimacy of secession-.

But throughout the process the secessionist movement has faced a far more serious problem: the absence of a majority of Catalan society in support of secession, a simple majority, never mind that 'clear majority as a qualitative evaluation' referred to as indispensable, in any case, by the Canadian SC in the Reference on Quebec secession (para. 87).

In 2010 nationalism had a comfortable majority, with over 1.5 million votes (around $49 \%$ of the total) and 76 seats out of 135 . The combination of non-nationalist parties accounted for $41.5 \%$ of votes - just under 1.3 million - and 59 seats. All this with a low turnout: $58.78 \%$. The secessionist process has slowly but surely transformed this situation. In the 2012 elections - in which, for the first time, CiU's Manifesto included the referendum 
('consultation') on the political future of Catalonia ('right to decide'), but without advocating independence - nationalism as a whole lost two seats and a little over $1 \%$ in terms of votes, but retained a comfortable majority in Parliament. The nationalists, together, obtained $47.89 \%$ - just over 1.7 million votes - and 74 seats, compared with 44.8 $\%$ - just over 1.6 million votes - and 61 seats for the non-nationalists, as a whole. Turnout climbed to $69 \%$. After the referendum of 9-N (2014), in the early elections of 2015, called as a 'plebiscite' in favour of independence by Convergència - already without Unió -, and ERC, under the ticket Junts pel si (Together for yes), the pro-independence parties lost further ground. With a turnout of over $75 \%$ - more than seven points higher than in the 2012 elections -, the parties that advocated secession obtained $47.7 \%$ of the votes - just under 2 million -, while those opposed to independence obtained $48.05 \%$ of the votes - around 100,000 more than the former-. However, the pro-independence groups formed an overall majority in the Parliament, with 72 seats against the 63 seats of the latter.

The forces in favour of independence, therefore, emerged from the 2015 elections having failed the 'plebiscitary' challenge, insofar as, contrary to what Junts pel sí had argued during the campaign, this coalition did not achieve majority electoral support in terms of number of votes; not even with the inclusion of the votes for CUP, which had not featured in the manifesto. Nevertheless, as the days and the weeks went by, within the proindependence forces the notion took root that the overall majority in Parliament legitimized their desire to call -and hold- the referendum on self-determination -even if it were suspended or annulled by the CC- and declare independence -unilaterally if necessaryif the pro-independence option triumphed in the referendum. The problems regarding the legitimacy of this option, however, were obvious, even to observers who could certainly not be described as opponents of the independence movement ${ }^{\mathrm{XVIII}}$.

Finally, after the referendum on self-determination of 1-O, and as a consequence of the dissolution of the Parliament of Catalonia as one of the measures under sec. 155 Const., the elections of December 2017 confirmed the trend that had been apparent since 2012. Turnout continued to increase, reaching $79.09 \%$, and in total the three parties advocating secession obtained $47.32 \%$ of the votes (just over 2 million, almost exactly the same as those obtained by the pro-independence option in the 1-O referendum), while the candidacies opposed to independence obtained, altogether, $50.72 \%$ of the votes (over 2.2 million votes). The latter led the former by almost $2.5 \%$ and 150,000 votes. Yet, once 
again, the former achieved an overall majority in Parliament, with 70 seats (two fewer than in the previous legislature and four fewer than in the 2012 elections) compared with 65 seats for the forces opposed to the declaration of independence (two more than in the 2015 elections and four more than in those of 2012) ${ }^{\mathrm{XIX}}$.

Irrespective of other considerations, strictly in terms of electoral support for the proindependence option, the electoral results obtained by the secessionist movement in 2015 did not constitute sufficient a base for the strategy followed in the two years of legislature. And certainly did not provide the minimum necessary grounds to make the leap to the unilateral declaration of independence which took place during the parliamentary sessions of October 10 and 26-27, 2017. The considerable popular support achieved by the secessionist movement, the impressive popular mobilization, quantitatively speaking, as well as the qualitative importance of the support for the movement within Catalan society ${ }^{\mathrm{Xx}}$ and the partisan attitude of the public media dependent upon the Government of Catalonia $^{\mathrm{XxI}}$, produced a blurred image of the support for independence. A distorted perception which the electoral results have corrected. In short, the independence movement has revealed remarkable strength, unimaginable only six years ago. But insufficient strength at this time to advocate such a strategy.

Everything stated so far reveals the major weaknesses of the secessionist claim, both in its theoretical construction and in its practical foundations. But one must ask oneself, at the same time, how such rapid growth of support for secession has been possible in a community where, traditionally, it had been so weak; what it is that has made possible such a severe fracture between a broad and significant sector of Catalan society and the Spanish political system.

In my opinion there are two elements which explain this process and its characteristics. Firstly, the perception shared by a large part of Catalan society that their aspirations were being ignored by part of the Spanish political system. The landmarks in the build-up to this perception are to be found - though, possibly, in a somewhat subjective retrospective reconstruction - in the process of amendment of the SA that concluded in 2006, following its conflictive processing in the lower House -and an aggressive campaign against the SA by the PP, in response to the party's exclusion from the process of its drafting-; in the CC ruling on the reform, in 2010, which has been canonised by the secessionist movement as a humiliation and an insult to the dignity of Catalonia ${ }^{\mathrm{xxI}}$; in the rejection of the proposal to 
improve the financing of Catalonia - the so-called 'Fiscal Agreement'- submitted by the then First Minister Artur Mas; and finally, in the perception of the impossibility of reforming the system of territorial autonomy in Spain.

Secondly, the process - and its characteristics- have been possible because the Spanish political system -in general, but firstly the PP's Government and the parliamentary majority supporting it - had not addressed the political debate arising from the nationalist claim and has relinquished the terrain of political debate to those who advocate secession as the only alternative $^{\mathrm{XxIII}}$. The sole argument employed in opposition to that claim has been the argument of legality, the rule of law: both the demand for a referendum on the political future of Catalonia and, even more so, the secession, are illegal, contrary to the Constitution, so there is nothing to be negotiated; not even anything to debate. And, in this sense, the idea has spread in some sectors in Spain that addressing a reform of the Constitution to reform the system of territorial autonomy, further exploring the federal path adopted in practice by the CC (Cruz Villalón, 2009), to resolve the problems arising from a constitutional model rooted in a Constitution - the republican Constitution of 1931- which specifically attempts to articulate a system differing from federal systems, would be a way of satisfying the secessionists -though the latter reject it as non-satisfactory, and must therefore be ruled out.

This has been, in my opinion, a politically evil process, marked by the irresponsible strategy employed by the secessionist movement and the, irresponsible too - though in a different way and to a different extent- lack of a political alternative on the part of the State (López Basaguren 2017b). There have been some particularly dark moments, on both sides of the conflict. The secessionists sank to their lowest point in the parliamentary sessions of 26-27 September, when they blatantly violated the rights of the opposition in the Catalan Parliament during passing of the 'laws of disconnection'. And they took a risky path when, on September 21, while members of the police, under the control of court staff, were conducting a search regarding the preparations of the referendum of 1-O, a secessionist mob laid siege to the headquarters of the Catalan Department of Economy, destroying police cars and preventing members of the police and of the court staff from leaving the buildings. Regarding the State's actions, the darkest day resulted from its attempt to impede the holding of the referendum of 1-O, with images of police repression that were broadcast all over the world, though what was said required much closer scrutiny than was generally 
the case (Preston 2017a). And the reaction by the State that is most difficult to understand is the investigating judge placing the leaders of the secessionist movement in precautionary prison and accusing them of rebellion, which, in opinion of several lawyers - and my own-, has weak legal grounds, insofar as -according to the Criminal Code- rebellion, on the one hand, involves 'violence' and, on the other, differs from 'sedition' in that the latter involves not 'violence' but ‘tumultuous acts' (López-Basaguren, 2017a: 314-315, and 2018).

\section{The measures of Federal Coercion in Catalonia}

Throughout the development of the process of the claims for the secession of Catalonia, there have been various acts of clear disobedience on the part of the authorities of the AC against the $\mathrm{CC}$ resolutions, in particular. The two moments when disobedience was especially evident involved the calling and holding of the referendums on the political future of Catalonia (9-N, 2014) and on self-determination (1-O, 2017).

The 'consultation' of the 9-N took place in spite of the suspension - by the CC, as an effect of sec. 161(2) Const. - of the Act and the Convening Order in accordance with which it was called, after these were challenged by the Government before the CC (LópezBasaguren 2017a: 303 ff. $)^{\text {xxIv }}$. The then First Minister-Artur Mas- and two members of his Government -Joana Ortega and Irene Rigau- were sentenced in first instance by the High Court of Justice of Catalonia -Ruling of March 13 2017- to different penalties and disqualification from public and representative office because of the crime of disobedience: two years of disqualification and a 1,200 € fine, the former, one year and nine months' disqualification and a 1,000 $€$ fine in the second case, and disqualification for a year and six months and an $800 €$ fine for the latter. The three were cleared of wilful neglect of duty. The appeal is pending a decision in the Supreme Court. No measures of federal coercion were applied at that time, but the Catalan authorities at the time did not contemplate taking any practical decision regarding Catalonia's secession as a result of such a 'referendum'.

Disobedience of the CC resolutions was reiterated in the new legislature, following the 2015 elections, on the path towards the referendum of the 1-O and UDI which followed the latter. Thus, one of the key moments of the process of disobedience of the CC resolutions was the Parliament's disobedience of the suspension and, subsequently, of the Constitutional Court Ruling (CCR259/2015, of December 2, 2015) which declared null and 
void, as contrary to the Constitution, the Resolution declaring the 'start of the process of creation of an independent Catalan State in the form of a Republic': it stated that, in the 'process of disconnection' from Spain, the Catalan institutions 'will not be subject to the decisions of the institutions of the Spanish State, and in particular of the Constitutional Court', which they regarded as lacking 'legitimacy' and 'competence'. The Resolution urged the Government to exercise only those mandates emanating from the Catalan Parliament (Resolution 1/XI of November 9, 2015).

The Parliament of Catalonia also ignored the suspension of the reform of the Standing Orders (sec. 135) adopted on July 26, 2017, which reformed the procedure known as 'single reading' that made it possible, during the same session, directly to present, debate and pass a Private Bill. The procedure imposes an extraordinary limit upon the time available for debate and the possibility of tabling amendments ${ }^{\mathrm{xxv}}$. Despite the suspension of the amendment, Parliament applied it in the procedure of adopting the Act of the referendum on self-determination (declared null and void by CCR 114/2017, of October 17) and the Act on Legal Transience and Foundational of the Republic, in the stormy session of September 6-7, 2017. The Government of Catalonia eventually organised and held the referendum of the $1-\mathrm{O}$ in spite of its having been suspended, after being challenged before the CC by the Spanish Government. And, finally, the Parliament of Catalonia, in two extremely chaotic sessions, without complying with what was established in the actual -but suspended- Act of the referendum on self-determination, passed the UDI: on October 10, without any vote and with its subsequent suspension by the First Minister- which in no case fell within his competence, according to the Act of the referendum-; and on the $26^{\text {th }}-27^{\text {th }}$, with vague contents in the Declaration adopted by the Parliament.

This last session of the Parliament of Catalonia was held at the same time as the processing in the Senate of the authorisation for the Government to apply the measures of federal coercion which it had proposed, after previously requesting of the First Minister of Catalonia -according to what is required by sec. 155 Const. - that he cease in his noncompliance with constitutional and legal obligations ${ }^{\mathrm{XxvI}}$.

At that moment the situation was completely different from that of November 2014. In October 2017 the Catalan Parliament and Government had formally declared that they would not comply with Spanish legal system (Catalonia, they said, had already been 
'disconnected' from Spain), refusing to apply either Spanish legislation or the decisions of its Courts -among them, those of the CC-; both, Parliament and Government had declared that they would apply the Acts of 'disconnection' passed by the Catalan Parliament; these Acts stated that in the event of the referendum producing more votes in favour than against independence - irrespective of the turnout achieved - the Parliament would declare the secession of Catalonia; Parliament and Government played with the UDI, passing and suspending and passing it again ${ }^{\mathrm{XXVII}}$.

The measures proposed by the Government to be adopted in the Senate were multiple, but their objective was essentially the removal of the members of the Government of Catalonia and the assumption of their competences by the Spanish Government, especially in the areas of security, the treasury and communications. But these measures were intended to be transitory and instrumental. The most important measure envisaged by the Spanish Government was the dissolution of the Parliament of Catalonia and the calling of early elections, a decision that was formally adopted by the Spanish Prime Minister, exercising the powers that corresponded to him having assumed those of the First Minister of Catalonia ${ }^{\text {XxvIII }}$. Many - myself included - considered that, on the one hand, the unexpected and surprising- dissolution of the Parliament was a measure that, in principle, posed problems of compatibility with the provision of sec. 155 Const., insofar as the latter refers to 'non-fulfilment of obligations', as grounds for activating 'federal coercion', and the reason for applying the latter is 'to compel the Community to meet said obligations'. But, on the other hand, it was believed, very generally, that this was politically intelligent, since, simultaneously, it limited intervention in the administration of the AC to a minimum and - the Spanish Government expected and hoped- imposed a time limit upon that intervention, in a politically special period of electoral campaign. And, eventually, it left the final decision in the hands of the voters, which would establish an indisputable way out of the political crisis in Catalonia.

The debate that took place in the Senate vis-à-vis authorising the Government's application of the proposed measures was relevant first of all in terms of procedure: the fact that it was previously reported in joint session (October 26) by the Select Committee on Constitution and the General Committee on Autonomous Communities. This confirmed the intention of attributing to the latter a central role in issues relative to territorial autonomy. But the debate demonstrated the consequences of the configuration of the Senate as 
Chamber of sober second thought, with no special character as Chamber of representation of the autonomous territories. The debate and the decision were dominated, fundamentally, by the two main parties at State level, who negotiated the terms of the Senate's decision on the basis of criteria of Spanish politics as a whole. The Senate, as demanded by the Socialist Party, eliminated one of the measures proposed by the Government: the control of the public media dependent upon the Government of Catalonia. In spite of the partisan defence of independence characteristic of these media, the Socialists believed that the fundamental right to freedom of information might be affected, so demanded this exclusion. Although the PP - in Government at that time - held an overall majority in the Senate, it -and the Government- considered that the support of the Socialists was politically essential in order to venture onto the unexplored path of federal coercion, so it acceded to this demand. This was the only relevant question raised in the Senate. On October 27, the Plenary of the Chamber authorised the Government to apply the measures included in sec. 155 Const. $^{\text {xxix }}$.

The adoption of the measures of federal coercion has given rise to a debate over their compatibility with the Constitution; and different appeals of unconstitutionality have been lodged -before the CC- against the Senate's authorisation, by both the Parliament of Catalonia and by a group of MPs belonging to Podemos, the left-wing party. In my opinion, there could be an incongruence between some of these measures and the wording of sec. 155 Const.. That incongruence might exist not only in the case of the dissolution of the Parliament, but also, previously, in the removal of the members of the Government, and firstly, its President. In my opinion, the aim of sec. 155 Const. is forcibly to impose fulfilment of constitutional and legal obligations not complied with by the authorities of a certain AC. All the measures that are necessary, as the Constitution states; but only those that are strictly necessary, as is required by the exceptional nature of such measures.

Therefore, the aim of measures adopted under sec. 155 Const. has to be compliance though compulsory- with the decisions that had been defied. Not punishment of those who have defied said decisions. There are two questions, at least, that have to be asked. Is it not a punishment to remove from office the members of a Government instead of giving them instructions and, in the event of continued defiance, suspending them until they comply? Removing an authority from office is a measure that only judges can take according to a due process. And, secondly, regarding the dissolution of Parliament, the 
issue is whether the strictly political declarative acts of a representative Chamber, which, not being self-executive, need 'executive' activity to have practical effects, can be a case of refusal to 'fulfil the obligations imposed upon it by the Constitution or other laws', as stated by the sec. 155 Const. This could be the case, on the one hand, of the UDI by Parliament, which is a declarative act, and, on the other, the executive acts needed for that declaration to become a reality (Lopez Basaguren 2017a: 314 ff.). In these cases, is control and -if appropriate- its nullification by the Courts -i.e., CC- not sufficient? ${ }^{\mathrm{Xxx}}$

Though it is not possible in this work to undertake an in-depth analysis of these questions, it is worthwhile - given the expressiveness of its position- to refer to the opinion of the Catalan Council on Guaranties of Autonomy -the advisory council of the institutions of Catalonia- when it informed Parliament on the viability of the appeal lodged before the CC against the application of sec. 155 Const. (Consell de Garanties Estatutàries 2017). On the issues debated, the Consell considers that, in spite of the fact that the measures of federal coercion have not been in the form of an Act, the Senate Decision to authorise them is open to challenge before the CC via the appeal of unconstitutionality - an appeal in accordance with which primary and secondary legislation is subject to control by this Court. Regarding this issue, it is necessary to take into account that the Organic Act on CC states -sec. 31- that the appeal of unconstitutionality can be lodged not only against 'Acts and regulations having the force of an Act [secondary legislation]' -as stated in sec. 161.1,a Const.- but also against 'decisions' having the same force. The 'decision' taken by the upper House in support of the measures of federal coercion could be, without a doubt, this kind of 'decision' having the force of an Act.

With regard to the measures adopted, the Consell considers the dissolution of Parliament to be compatible with the Constitution, though it considers that in the prior notification the Central Government should have warned the Government of Catalonia that this dissolution might be one of the measures adopted in the event of non-compliance. The Consell considers that this measure is covered by sec. 155 Const. insofar as Parliament 'is responsible for passing Acts of referendum on self-determination and on Legal Transience and Foundational of the Republic with the corresponding effects and subsequent acts of undermining of the constitutional order and prevailing statutory law' ( $p$. 55). And, at the same time, it thinks that it is the most proportionate and shortest-lasting measure, allowing for rapid re-establishment of institutional normality. On the other hand, 
the Consell considers that the removal of the members of the Government of Catalonia is not covered by sec. 155 Const., because it is contrary to the principles of gradualism and proportionality, insofar as the objective of the measures of federal coercion could have been achieved via other less drastic and definitive measures, e.g., suspension from office (p. 69).

The issue, in any case, is pending resolution by the CC. Meanwhile, the situation in Catalonia has been singular, in that the political process following the December elections was paralysed, with a Parliament in which the pro-independence parties continue to have a majority - albeit, apparently, with varying strategic goals-. After the December elections, the Parliament opened the new (XII) Legislature on January, 2018. But it was not able to appoint the First Minister -Joaquim Torra- until May, 14, after various attempts to propose different candidates who had fled from Spain -Carles Puigdemont- or who were in prison Jordi Turull-. Following the first investiture vote on March 22 -for the candidate Jordi Turull, not yet in prison-, which failed, it would be necessary to repeat elections if the Parliament were unable to elect a First Minister before May 22. After the appointment of the new First Minister some time was still required in order for the Government members to be nominated (June, 1) since the First Minister attempted to appoint as Ministers some people in prison and the Spanish Government, still competent under the measures of federal coercion, refused to accept these nominations. Hopes that the dissolution of Parliament and the calling of elections in December would guarantee a rapid return to political normality have largely faded.

\section{Final Remarks: the need to reform a useless Senate}

The Spanish Senate, despite its constitutional description as 'House of territorial representation', fulfils a function as a Chamber of sober second thought, completely subordinate to the lower House, in which its function with regard to territorial autonomy is in practical terms thoroughly diluted. The absence of a 'territorial' role occurs, even, when the Senate is exclusively responsible for a function linked to territorial autonomy, as is the case of authorisation of measures of 'federal coercion' referred in sec. 155 Const.

Firstly, the composition of the Senate is decisive in this incapacity to play an active role in the channelling of interests related with territorial autonomy. It is not only the fact that 
the vast majority of senators are elected upon a provincial basis and this radically distorts the territorial origins of the members vis-à-vis the relative demographic weight of the different ACs and also distorts the political orientation of this Chamber. It is also the fact that, as a consequence of the electoral system and the absolute power of the leadership of the parties in the designation of - or support for- candidates, the members of the Chamber respond, absolutely, to a dynamic of party rather than territorial interests. Moreover, finally, nobody, neither parties nor ACs, has ever felt the need to channel their territorial interests via the upper House. It is in the lower House that the interests of the ACs are channelled. This is evident in the cases where the AC is governed by one of the two major parties that have alternated in Government; as it is in the cases of the nationalist parties - the Basque and Catalan cases are the most significant - or by regionalist parties, regardless of whether or not they control the Government of the AC, although their viability is conditioned by political context and parliamentary arithmetic.

It is extremely difficult for a Chamber constituted thus and accustomed to functioning in a manner subordinate to the political dominance of the lower House, with the members of the Senate having an absolutely secondary role, to be able to act according to territorial interests when it has to exercise a function within the sphere of territorial autonomy, even if it enjoys exclusive competence. The experience of the General Committee on $A C$ is very significant in this respect.

On the other hand, the attempt to reinforce in the upper House activity, debate and proposals in questions of territorial autonomy soon petered out, after the initial impact arising from the novelty of the initiative. The functioning of the party system has not changed and the parties have not assigned the General Committee on $A C$ the leading role regarding territorial autonomy. The same conclusion can be drawn from the extraordinary procedure to authorise the measures of coercion proposed by the Government, under sec. 155 Const. regarding the Catalan authorities' defiance of their legal obligations. The debate and its contents were in no way different from what would have been witnessed in the lower House.

There is an almost unanimously held opinion among scholars, which dates from the very birth of the Constitution (Aja Fernández 1979), that the Senate is a completely useless Chamber and that the reform of the Constitution in this regard is absolutely essential. But there is no unanimity regarding the type of Senate that Spain needs. A considerable 
majority of authors attempt to materialise the constitutional declaration of the Senate as Chamber of territorial representation, but not all the proposals coincide. Most authors favour the introduction of a Senate following the model of the German Bundesrat (Aja Fernández 2005), which is certainly very popular amongst Spanish scholars, though opposing stances do exist (Portero Molina 1995: 98 ff.; Solozábal Echavarría 1995: 74 ff.). There are also those who advocate, purely and simply, its disappearance, considering it to be 'a remnant of history that contributes little to the federal structure' (Sáenz Royo 2014: 64). I have the impression that, in any case, reform of the Senate in the sense of it becoming a Chamber of representation of the AC, whatever the formula, faces considerable resistance in the political world, particularly sensitive to the possible impact of the proposed reform upon the number of Senators the corresponding party might reasonably aspire to and how this would compare with the existing situation: the Senate offers a large number of representative posts, employed on many occasions as destinations for distinguished members who have abandoned front-line party activity.

Reform of the Senate was contemplated within the limited -and excessively formalist, in my opinion- proposal for constitutional reform made by prime minister Rodriguez Zapatero in the investiture debate of 2004. A proposal that gave rise to an acclaimed Report by the Council of State, then presided over by Prof. Rubio Llorente (Álvarez Junco \& Rubio Llorente 2006), highlighting the major problems posed by any intended constitutional reform of the Senate.

In any case, what the present system has shown is that without significantly altering the Senators' provenance and without transforming the Senate's powers within the parliamentary system, any attempt to assign it a leading role in relation to territorial autonomy appears to be almost inevitably doomed to failure.

\footnotetext{
* Professor of Constitutional Law. University of the Basque Country -UPV/EHU- (Spain). Email: alberto.lopez@,ehu.eus. University's Research Group PPGA18/12. This paper has been written as a contribution to the Research Project DER 2017-86988-P, funded by the Ministry of Economy and Competitiveness (MINECO) -now, Ministry of Science, Competitiveness and Universities-.

I am grateful to the two anonymous reviewers who evaluated this paper for their helpful comments regarding a previous draft.

I There is obviously a considerable amount of academic literature in Spanish on the subject of the Senate. In English, the most complete work is that of Castellà 2013.

II Spain is divided into 50 provinces. However, for the purposes of the election of Senators, under sec. 69 (3) of the Constitution, the island provinces appoint 'three Senators for each of the major islands - Gran Canaria, Mallorca and Tenerife - and one for each of the following islands or groups of islands: Ibiza-Formentera, Menorca, Fuerteventura, Gomera, Hierro, Lanzarote and La Palma.' In addition, 'the cities of Ceuta and Melilla
} 
shall elect two Senators each.'

III In any case, of the $17 \mathrm{ACs}$ in Spain, seven were formed on the basis of a single Province: Asturias, Cantabria, Navarra, La Rioja, Madrid, Murcia and the unique case of the Balearic Islands.

IV This is what explains the political majorities that usually exist in the Senate. The current legislature is a good example. While the lower Chamber has witnessed a significant diversification of representation, with the traditional two-party system significantly weakened, complemented by the existence of significant territorially localised -nationalist- minorities, in the Senate the conservative PP -the party in Government until the vote of no confidence of June, 1- retains a comfortable overall majority -148 seats-, followed, at some distance, by the Socialist Party -62 seats-, with a very minority representation of the other parties: 20 seats Podemos, 12 Esquerra Republicana de Catalunya, 6 the PNV - Basque nationalists-, 6 the PdCAT - former Convergència, Catalan nationalists- and 12 other small parties.

$\mathrm{V}$ The Organic Act is a type of reinforced Act, reserved for the regulation of the development of fundamental rights, the electoral system, the SA and, in general, the regulation of the constitutional institutions of the State (sec. 81 Const.).

VI The Senate Standing Orders establish the possibility of the formation within the Parliamentary Groups of 'Territorial groups' (sec. 32), with a certain capacity for autonomous intervention in the Chamber (García Fernández 1984), but the sum of their activity has been practically irrelevant (Punset Blanco 2006: 112)

VII This drafting was introduced into the reform of the Standing Orders adopted on June 29, 2005: see. Boletin Oficial de las Cortes Generales, Senado, serie III A, n. 31, of June 30, 2005. Until then, the various official languages of the AC could only be used in the Senate in the annual debate on the AC - to which I shall refer below- and in the symbolic case of the President of the Chamber's speech in the opening address on the first day of the legislature. VIII Sec. 56 bis (5) of the Standing Orders establishes, in the same vein, that Senators appointed by a certain AC who are not members of the General Committee shall be able to participate in any Committee established to examine issues that specifically affect a particular AC.

IX One of the most relevant initiatives of the General Committee was the adoption, in the first debate on territorial autonomy (September 28, 1994), of the PP's proposal to create the Conference of Presidents, to bring together the Prime Minister and the First Ministers of the ACs. But the Conference was not created until 2004, when it first met. To date, it has met on six occasions (2004, 2005, 2007, 2009, 2012, and 2017).

x In any case, it was argued at the time (García de Enterría 1983: 163 ff.) that sec. 155 was not a simple transfer of 'federal coercion' (Bundeszwang) from sec. 37 GG, but an amalgam of that provision and of the 'federal oversight' (Bundesaufsicht) of sec. 84 GG. Upon this basis, the prestigious jurist was attempting to 'de-dramatize' the interpretation of the constitutional provision, defending its 'ordinary' nature as an instrument of relationship between the State and the AC, at least in the execution of State legislation by the autonomous territories. In this sense, he differentiated between what he called the 'declarative stage' (federal oversight) and the 'enforcement phase' (federal coercion). The 'declarative stage' was what was activated in 1989 against the AC of the Canary Islands, when its Government refused to apply the elimination of its territory's import tariffs, provoking a conflict with the EU and with the Spanish Government. Negotiations between both Governments led to an agreement that all parties regarded as satisfactory.

XI A different matter is the adoption of purely 'political' measures like the declaration of 'extraordinary', situations such as 'states of emergency and siege (martial law)', regulated in sec. 55(1) and 116 of the Constitution.

XII In this sense, the CC has said more than once that sec. 155 establishes an 'extraordinary tool': CCR 6/1982 of 22 February ('an extraordinary control'); CCR 49/1988 of 22 March ('an extraordinary means of obligation, not appropriate for the resolution of common matters'); CCR 215/2014 of 18 December ('a last reaction against a flagrant breach of obligations imposed by the Constitution').

XIII The term 'ordinary' legislation is used in counter-position to 'constitutional'. This is the case of the Act on Budgetary Stability - Organic Act 2/2012, of April 27-, under which non-compliance by the AC with the consequences arising from non-compliance with objectives of budgetary stability and of the economic-financial plan will allow the Government to apply the measures provided for in sec. 155 Const. in order to force compulsory compliance (sec. 26). This is an unnecessary provision, since it does no more than reproduce what is established in sec. 155 Const. But it made it possible to introduce federal coercion into 'ordinary' legal language.

XIV With regard to the secessionist process in Catalonia, the CC has not applied these new instruments attributed to it by the law. It seems relevant that no Catalan authority was suspended despite the clear defiance of the CC's decisions regarding the referendum of 1-O; and that only in relation to that referendum did it impose periodic penalty fines upon the members of the Electoral Commission (Sindicatura electoral), whose task was to supervise the referendum process and to announce the results. The CC's decision resulted in the immediate withdrawal of 
the Commission members, so there was neither supervision of the process nor official announcement of the results.

XV A more detailed analysis can be found in the following works: Castellà Andreu 2014 and 2016; Ferreres Comella 2014 and 2016; Fossas Espadaler 2014; López-Basaguren 2016a, 2016b and 2017; Tornos Mas 2014 and 2015; Tudela Aranda 2016; in a critical vein. In defence of the process and of the claim for secession, see Barceló et al. 2015; Ridao 2014; Vintró Castells 2012; as well as the texts gathered in Kraus et al. 2017.

XVI Although there are conflicting interpretations with regard to its impact upon the beginning of the process, at least indirectly, in its origin is the frustrating conclusion to the process of reform of the SA of Catalonia (2006), the final milestone being the CC ruling (CCR 31/2010, of June 28) declaring contrary to the Constitution -and, consequently, null and void- twelve clauses in different articles of the SA, establishing, in addition, how different clauses in another twenty-seven articles had to be understood to be consistent with the Constitution. The bibliography upon the reform of the SA of Catalonia and on the corresponding CCR is extensive in Spanish and Catalan. In English, see López-Basaguren 2013: 400 ff.

XVII The reports of the Consell assessor per a la transició nacional are accessible at https://www.ara.cat/politica/informe-consell-assessor-transicio-nacional_0 1120088191.html; the official website of the Generalitat of Catalonia only has the last eight reports of the Consell (http://premsa.gencat.cat/pres fsvp/AppJava/notapremsavw/274452/ca/catn-conclou-independenciasuposaria-guany-fiscal-d11-600m-deuros-i-garanteix-viabilitat-pensions.do).

XVIII In this sense, immediately after the elections of September 2015, M. Keating (2015) stated, in relation to the first of the pro-independence options (unilaterally declare independence): Prominent members of the civil society pro-independence movements have long advocated this. Yet, without a majority of the popular vote, this looks democratically dubious. It is also formidably difficult as a practical matter, as it would require international recognition and the loyalty of citizens to the new state.'

XIX In this process there has been another highly significant event: the profound internal transformation of each of the political sectors configured in relation to the question of independence, with the strengthening in each of them of the political forces occupying a more radical position in favour of or against independence. But this is neither the time nor the place to analyse this question.

$\mathrm{xx}$ Until very recently, the most significant figures in Catalan society who appeared and spoke in public in relation to the political process did so in support of the demand for independence.

XxI See the considerations of the experienced former editor of The Guardian P. Preston (2017b).

XXII Indeed, 'The dignity of Catalonia' was the title of the joint editorial of the Catalan press as a whole published on November 26, 2009, on the CC ruling on the reform of the SA, that was still being drafted, over three years after the appeal was lodged-.

XXIII One of the favourite - and most effective- arguments employed by the secessionists is that it is easier to achieve the independence of Catalonia than it is to reform the - constitutional - system of territorial autonomy. The answer to that conviction comes, however, via the very history of Catalonia, in relation to the proclamation of the Catalan Republic on October 6, 1934, during the Spanish Second Republic, from one of the sharpest observers of those events, A. Calvet, Gaziel $(2013,135)$ at that time editor of the newspaper La Vanguardia: 'The separatist believes that it is impossible to get along with the rest of the Spaniards, and to resolve this situation, proposes something even more difficult, which is violently to part with them. He feels incapable of making the necessary effort in order to exert influence in Spain, and dreams instead of the mighty objective of breaking free once and for all from its formidable influence. To escape one difficulty he creates a greater one. But if he lacks the strength to resolve the smaller problem, how is he going to deal with the bigger one?'

xxIV Both were, finally, declared null and void, as contrary to the Constitution: CCR 31 and 32/2015, of February 21.

xxv The procedure, moreover, prevented opposition groups from requesting a report from the Consell de Garanties Estatutaries. This organ recalled that the right to request the Opinion upon the presentation of a Bill is a fundamental right of the members of Parliament: see CONSELL DE GARANTIES ESTATUTÀrIES: Acord del Ple del Consell de Garanties Estatutàries, of September 6, 2017 and Acord del Ple del Consell de Garanties Estatutàries, of September 7, 2017. The CC resolved the appeal via Ruling 139/2017, of November 29, in which it considers that the reform of article 135 of the Regulation is constitutional insofar as it is interpreted solely in the sense that it allows for the presentation of partial or total amendments to the Bill by the parliamentary groups.

Xxvi See the Government Decision proposing the measures of 'federal coercion' in Boletin Oficial del Estado n. 260I, of October 27, 2017.

XXVII The former Catalan Minister of Education, Clara Ponsatí, has recently declared: 'We were playing poker and 
we were bluffing': see Ara.cat (electronic newspaper), 09.06.2018

xxvIII See the Decree of the President of the Spanish Government calling for elections in Catalonia to be held on December 21, 2017 -Royal Decree 946/2017, of October 27- in Boletin Oficial del Estado, n. 261-I, of October 28. XxIx The debate in the joint session of the Select Committee on Constitution and of the General Committee on Territorial Autonomy, in Diario de Sesiones. Senado. XII Legislatura, Comisión Conjunta de las Comisiones General de las Comunidades Autónomas y Constitucional, n. 183, 26.10.2017. The debate in the Plenary, in Diario de Sesiones. Senado. XII Legislatura, Pleno, n. 45, 26.10.2017.

Xxx The CC, however, adopted a different stance by declaring the unconstitutionality of Resolució 5/X of 23 January 2013 (Butlletí Oficial del Parlament de Catalunya, X Legislature, n 13, 24.01.2013) in CCR 42/2014, of March, 25 (Fossas Espadaler 2014; Ferreres Comella 2016).

\section{References}

- Aguado Renedo César, 1996, El estatuto de autonomía y su posición en el ordenamiento jurídico español, CEPC, Madrid.

- Aja Fernández Eliseo, 1979, 'Por un Senado de las nacionalidades y regiones', in Trujillo Gumersindo (ed), Federalismo y regionalismo, CEPC, Madrid, 447-466

- Aja Fernández Eliseo; Albertí Rovira Enoch; Ruiz Ruiz Juan J., 2005, La reforma constitucional del Senado, CEPC, Madrid.

- Álvarez Junco José and Rubio Llorente Francisco, 2006, El informe del Consejo de Estado sobre la reforma constitucional: texto del informe y debates académicos, CEPC/Consejo de Estado, Madrid.

- $\quad$ Bagehot Walter, 1873, The English Constitution, 2nd edition, Little, Brown \& Company, Boston.

- Ballart Hernández Xavier, 1987, Coerció estatal i autonomies. Estudi de l'article 155 de la Constitució de 1978, Escola d'Administració Pública de Catalunya, Barcelona.

- Barceló Serramalera Mercè \& Corretja Mercè, 2015, 'El derecho a decidir en Cataluña; cronología de la construcción de un nuevo derecho democrático', federalismi.it. Rivista di Diritto pubblico italiano, comparato, europeo, no. 4/2015 (accesible

at http:/ / federalismi.it $/$ ApplOpenFilePDF.cfm?artid=28881\&dpath=document\&dfile $=24022015125800$.pdf\& content $=\mathrm{El}+$ derecho $+\mathrm{a}+$ decidir + en $+\mathrm{Catalu} \% \mathrm{C} 3 \% \mathrm{~B} 1 \mathrm{a}:+$ cronolog $\% \mathrm{C} 3 \% \mathrm{ADa}+\mathrm{de}+\mathrm{la}+\operatorname{construcci} \% \mathrm{C} 3 \% \mathrm{~B} 3 \mathrm{n}$ + de+un + nuevo + derecho + democr $\% \mathrm{C} 3 \%$ A1tico+-+stato+-+dottrina+-+).

- $\quad$ Calvet Agustí (Gaziel), 2013, Tot s'ba perdut, RBA/La Magrana, Barcelona.

- $\quad$ Castellá Andreu Josep M., 2006, 'The Spanish Senate after 28 years of Constitutional Experience. Proposals for Reform', in Luther, Jörg et al. (eds), A World of Second Chambers. Handbook for Constitutional Studies on Bicameralism, Giuffrè, Milano, 859-909.

- Castellà Andreu Josep M., 2014, 'Secesión y referéndum sobre el “derecho a decidir” en Cataluña. Una aproximación desde el Derecho Constitucional', in Oliver Araujo Joan (ed), El futuro territorial del Estado español. ¿Centralización, autonomía, federalismo, confederación o secesión?, Tirant lo Blanch, Valencia, 451-490.

- Castellà Andreu Josep M., 2016, 'Tribunal Constitucional y proceso soberanista catalán: respuestas jurídico-constitucionales a un conflicto político-constitucional', Teoría y Realidad Constitucional, no. 37: 561-592.

- Consell de Garanties Estatutàries de Catalunya, 2017, Dictamen 14/2017, de 5 de desembre, sobre la Resolució de 27 d'octubre de 2017, de la presidència del Senat, per la qual es publica l'Acord del Ple del Senat, pel qual s'aproven les mesures requerides pel Govern, a l'empara de l'article 155 de la Costitució.

- Cruz Villalón Pedro 1983, ‘Reserva de Constitución? (Comentario al fundamento jurídico cuarto de la Sentencia del Tribunal Constitucional 76/1983, de 5 de agosto, sobre la LOAPA)', Revista Española de Derecho Constitucional, no. 9: 185-208.

- Cruz Villalón Pedro 2009, 'La dificultad del Tribunal Constitucional como garante de la autonomía territorial', Revista catalana de Dret Public, 39, 21-36

- De Miguel Bárcena Josu, 2016, 'Manual para construir un Estado (Los informes del Consejo Asesor para la transición nacional de Cataluña)', Teoría y Realidad Constitucional, no. 37: 499-527.

- Ferreres Comella Víctor, 2014, 'The Spanish Constitutional Court Confronts Catalonia's "Right to Decide" (Comment on the Judgment 42/2014', European Constitutional Law Review, X(3): 571-590. 
- $\quad$ Ferreres Comella Víctor, 2016, 'Cataluña y el derecho a decidir', Teoría y Realidad Constitucional, no. 37: 461-475.

- Fossas Espadaler Enric, 2014, 'Interpretar la política. Comentario a la STC 42/2014, de 25 de marzo, sobre la Declaración de soberanía y el derecho a decidir del pueblo de Cataluña', Revista Española de Derecho Constitucional, no. 101: 273-300.

- García Fernández Javier, 1984, 'Los Grupos Territoriales del Senado', Revista de Derecho Político, no. 21: 141-160.

- García Morales María Jesús, 2013, 'Intergovernmental Relations in Spain and the Constitutional Court Ruling on the Statute of Autonomy of Catalonia: What's Next?', in López-Basaguren Alberto et al., The Ways of Federalism in Western Countries and the Horizons of Territorial Autonomy in Spain, Springer, Heidelberg, 83-109.

- García Morales María Jesús, 2016, 'El Gobierno central y los Gobiernos autonómicos en España... ¿Trabajan juntos?’, Istituzioni del federalismo, XXXVII(1): 117-161.

- García-Escudero Márquez Piedad, 1994, 'La Comisión General de las Comunidades Autónomas (Reforma del Reglamento del Senado)', Revista de Administración Pública, 133, 485-500

- García de Enterría Eduardo, 1983, La ejecución autonómica de la legislación del Estado, Civitas, Madrid.

- Generalitat de Catalunya. Centre d'Estudis d'Opinió, 2018, Enquesta sobre context polític a Catalunya. 2018, REO n. $\quad$ 874, 23/02/2018 (accessible http://ceo.gencat.cat/ca/barometre/detall/index.html?id=6508).

- $\quad$ Keating Michael, 2015, 'What next for Catalonia?', Centre on Constitutional Change, Blog, published on October 1, (accessible at https://www.centreonconstitutionalchange.ac.uk/blog/what-next-catalonia).

- Kotzur Markus, 2006, 'Federalism and Bicameralism -The German "Bundesrat" (Federal Council) as an Atypical Model', in Luther, Jörg et al. (eds), A World of Second Chambers. Handbook for Constitutional Studies on Bicameralism, Giuffrè, Milano, 257-290.

- Kraus Peter A. \& Vergés Grifa J. (eds), 2017, The Catalan Process. Sovereignty, Self-Determination and Democracy in the 21st. Century, IEA, Barcelona.

- López-Basaguren Alberto, 2013, 'Current Issues around Territorial Autonomy in Spain', in LópezBasaguren Alberto et al. (eds), The Ways of Federalism in Western Countries and the Horizons of Territorial Autonomy in Spain, Springer, Heidelberg, 395-419.

- López-Basaguren Alberto, 2016a, 'Scottish referendum and Catalan “consultation": two experiences in the mirror', in Otaola Paloma et al. (eds), Autonomies et indépendences: le nationalisme au XXI ${ }^{e}$. siècle, Éditions Connaissances et Savoirs, Paris, 119-152.

- López-Basaguren Alberto, 2016b, 'Demanda de secesión en Cataluña y sistema democrático. El procés a la luz de la experiencia comparada', Teoría y Realidad Constitucional, no. 37: 163-185.

- López-Basaguren Alberto, 2017a, 'Regional Defiance and the enforcement of federal Law in Spain. The claims for sovereignty in the Basque Country and Catalonia', in Jakab András et al. (eds), The Enforcement of EU Law and V alues. Ensuring Member State's Compliance, OUP, Oxford, 300-315.

- López-Basaguren, Alberto, 2017b, 'Esperando a Godot', El País newspaper, October 11.

- $\quad$ López-Basaguren Alberto, 2018, 'Escrutinio judicial europeo', El Correo newspaper, April 7.

- López-Laborda Julio, 2012, 'The assignment of revenue to Spain's Autonomous Regions', SEFO. Spanish Economic and Financial Outlook, I(4): 73-77.

- Morales Arroyo José M. \& Gutierrez Rodriguez Francisco J., 1994, 'Un intento de territorialización del Senado: la Comisión General de las Comunidades Autónomas’, Administración de Andalucia. Revista Andaluza de Administración Pública, no. 20: 305-336.

- Muñoz Machado Santiago, 1983, 'La interpretación de la Constitución, la armonización autonómica y otras cuestiones (La Sentencia del Tribunal Constitucional de 5 de agosto de 1983: asunto LOAPA)', Revista Española de Derecho Constitucional, no. 9: 117-145.

- $\quad$ Portero Molina José A., 1995, 'Contribución al debate sobre la reforma del Senado', Revista de Estudios Politicos, no. 87: 81-105.

- $\quad$ Preston Peter, 2017a, 'Violence in Catalonia needed closer scrutiny in age of fake news', The Guardian newspaper, October 8.

- Preston Peter, 2017b, 'Catalonia's dreams of secession were incubated in a media cocoon', The Guardian newspaper, October 15. 
- $\quad$ Punset Blanco Ramón, 2006, 'De un Senado a otro. Reflexiones y propuestas para una reforma constitucional', Teoría y Realidad Constitucional, no. 17: 107-142.

- Requejo Rodriguez Paloma, 2013, 'La resurrección del interés general en el Estado autonómico', Revista de Derecho Político, no. 87: 149-178.

- $\quad$ Ridao Martín Joan, 2014, El Dret a decidir. La consulta sobre el futur polític de Catalunya, IEA, Barcelona.

- Ripollés Serrano M. Rosa, 1995, 'La participación del Gobierno y de los Consejos de Gobierno de las Comunidades Autónomas en la Comisión General de las Comunidades Autónomas del Senado', in Corts. Anuario de Derecho Parlamentario, no. 1: 11-30.

- $\quad$ Sáenz Royo Eva, 2014, Desmontando mitos sobre el Estado autonómico, Marcial Pons, Madrid.

- Solozábal Echavarría Juan J, 1995, 'Presupuestos y límites de la reforma constitucional del Senado', Autonomies. Revista catalana de Dret Public, no. 20: 61-77.

- Tornos Más Joaquín, 2014, 'El problema catalán: una solución razonable', El Cronista del Estado Social y Democrático de Derecho, no. 42: 44-53.

- Tornos Mas Joaquín, 2015, De Escocia a Cataluña. Referéndum y reforma constitucional, Iustel, Madrid.

- Tudela Aranda José, 2016, 'El derecho a decidir y el principio democrático', Teoría y Realidad Constitucional, no. 37: 477-497.

- Varela Suanzes-Carpegna Joaquín, 2006, 'La reforma del Senado', Teoría y Realidad Constitucional, no. 17: 143-168.

- Vilalta Maite, 2016, 'Pasado, presente y futuro de la nivelación en el modelo de financiación de las Comunidades Autónomas', Mediterráneo Económico, no. 30: 87-116.

- Vintró Castells Joan, 2012, 'Legality and the referendum on independence in Catalonia', Blog del Institut de Dret Públic, posted on 23 October (http://idpbarcelona.blogspot.com.es/2012/10/legalidad-y-consultasoberanista-en.html).

- Vírgala Foruria Eduardo, 2005, 'La coacción estatal del artículo 155 de la Constitución', Revista Española de Derecho Constitucional, no. 55: 58-116.

- Visiedo Mazón Francisco J., 1997, La reforma del Senado. Territorialización del Senado, Comisión General de las Comunidades Autónomas, Senado, Madrid.

- Zabalza Antoni \& López-Laborda Julio, 2011, 'The new Spanish system of Intergovernmental Transfers', Int. Tax Public Finance, XVIII(6): 750-786. 